\title{
Complement Factor D
}

National Cancer Institute

\section{Source}

National Cancer Institute. Complement Factor D. NCI Thesaurus. Code C84326.

Complement factor D (253 aa, $\sim 27 \mathrm{kDa}$ ) is encoded by the human CFD gene. This protein plays a role in the activation of the alternate complement pathway. 